\title{
Factors Affecting Somatic Cell Counts and Their Relations with Milk and Milk Constituent Yield in Buffaloes ${ }^{1}$
}

\author{
M. Cerón-Muñoz, H. Tonhati, J. Duarte, J. Oliveira, \\ M. Muñoz-Berrocal, and H. Jurado-Gámez \\ Faculdade de Ciências Agrárias e Veterinárias \\ Universidade Estadual Paulista \\ Jaboticabal, São Paulo, Brazil
}

\section{ABSTRACT}

Data concerning daily milk yield (MY), percentage of milk fat $(\% \mathrm{~F})$, protein $(\% \mathrm{P})$, lactose $(\% \mathrm{LT})$, and total solids (\%TS), and somatic cell counts (SCC) for a herd of 222 Murrah buffalo reared in the state of São Paulo, Brazil, were collected monthly from 1997 to 2000 in order to study the factors affecting SCC and their relation to milk production and constituents during lactation. SCC decreased in the second month of lactation and increased thereafter, up to the ninth month of lactation. The interaction of month of lactation $\times$ order of calving was significant. Mean MY observed during the first month of lactation was $6.87 \mathrm{~kg}$, which increased to $7.65 \mathrm{~kg}$ during the second month, and then decreased until the ninth month of lactation $(3.83 \mathrm{~kg})$. During the different months of lactation, $\% \mathrm{~F}, \% \mathrm{P}$, $\% \mathrm{LT}$, and \% TS ranged from 6.28 to $8.38 \%, 4.05$ to $4.59 \%, 4.96$ to $5.34 \%$, and 16.94 to $18.55 \%$, respectively. Calving year, calving order, and order of month of lactation significantly affected $\mathrm{MY}, \% \mathrm{~F}, \% \mathrm{P}, \% \mathrm{LT}$, and \%TS. The regression coefficients of transformed SCC on MY and \%LT were negative and significant during all months of lactation, showing that milk and lactose yield decreased with increased transformed SCC, causing losses to buffalo milk producers.

(Key words: fat, lactose, mastitis, milk, protein, total solids)

Abbreviation key: $\% \mathbf{F}=$ percentage fat, $\% \mathbf{L T}=$ percentage lactose, $\mathbf{M Y}=$ milk yield, $\% \mathbf{P}=$ percentage protein, SCCt $=$ transformed somatic cell count, \% $\mathbf{T S}$ $=$ percentage total solids.

\section{INTRODUCTION}

Mastitis is a disease that leads to reduced milk yield (MY) and an increased number of clinical treatments

Received January 30, 2002.

Accepted July 1, 2002.

Corresponding author: M. Cerón-Muñoz; e-mail: mceronm@ hotmail.com.

${ }^{1}$ Financial support: FAPESP/CNPq-Brazil. and early cow culling (Shook, 1989; Gill et al., 1990; Beaudeau et al., 1993; Lescourret and Coulon, 1994). This inflammation of the mammary gland, usually a response to invasive agents, can be characterized by an increase in SCC. This trait, or a logarithmic transformation called somatic cell score (SCCt), was used as an indicator of udder health for management and selection purposes (Rodriguez-Zas et al., 2000). SCC values higher than $283,000 \mathrm{cell} / \mathrm{s} / \mathrm{ml}$ indicate the presence of mastitis (Guidry, 1985; Reneau, 1986).

The established association between milk production and SCC in dairy cattle is increasingly used to estimate lost production due to mastitis because important management decisions regarding cost-effective prevention and control of mastitis are based on this relationship (Bartlett et al., 1990). Jones (1986) suggested that SCC of 0.6 to 1 million cells $/ \mathrm{ml}$ were associated with an 8 to $12 \%$ reduction in herd milk production. According to Harmon (1994), the mastitis or elevated SCC is associated with a decrease in lactose, $\alpha$-lactalbumin, and fat in milk because of reduced synthetic activity in the mammary tissue.

The phenotypic correlations between average SCC during lactation and total production of milk and of its constituents seem to be negative. Welper and Freeman (1992) obtained estimated correlations ranging from -0.15 to -0.01 between SCC and total production of milk, fat, protein, and lactose. However, the lactation average SCC does not use all the information and masks short-term variation in SCCt (Shook and Schutz, 1994). Since SCC in uninfected cows is high at freshening, lowest from peak to mid-lactation, and highest at drying off, a plot of monthly SCC would usually be the inverse of the lactation curve (Reneau, 1986). Harmon (1994) suggested that a modest rise in the SCC of uninfected quarters at the end of lactation is in fact a dilution effect.

Test-day somatic cell records are taken on the same cow at various times, providing longitudinal information that can be related more meaningfully to episodes of infection, and statistical modeling may provide more 
Table 1. Summary of lactation records characteristics of test day in buffalo milk.

\begin{tabular}{lc}
\hline Order of parity & Number of lactations \\
\hline 1 & 125 \\
2 & 102 \\
3 & 87 \\
4 & 71 \\
5 & 39 \\
Year of parity & Number of lactations \\
\hline 1997 & 47 \\
1998 & 97 \\
2099 & 124 \\
\hline
\end{tabular}

accurate estimates of the influence of risk factors than lactation average models (Rodriguez-Zas et al., 2000).

In buffalo herds reared in the state of São Paulo, the prevalence of clinical and subclinical mastitis is $1.5 \%$ and $18.77 \%$ among lactating buffaloes, respectively (Costa et al., 2000), leading to decreased MY and quality. This directly interferes with the production of Mozzarella cheese, originally prepared from buffalo milk. The European Union Directives (92/46CEE and 94/71 CEE) set a limit of 400.00 cells $/ \mathrm{ml}$ for SCC in raw buffalo milk, when the milk is used for products made with raw milk.

Thus, the objective of the present investigation was to study the influence of factors on the test day on SCC and its relations with the production of milk and of its constituents during lactation in buffalo.

\section{MATERIALS AND METHODS}

A total of 2693 records concerning daily MY, percentages of fat $(\boldsymbol{\%} \mathbf{F})$, protein $(\boldsymbol{O P})$, lactose (\%LT), and total solids (\%TS) were analyzed, in addition to data concerning SCC obtained monthly from 1997 to 2000. The distribution of records and buffaloes by year and parity are summarized in Table 1. The lactations of 222 Murrah buffaloes were observed on the Santa Eliza farm, Dourado County, SP, Brazil. The farm is located at $48^{\circ} 19^{\prime} 30^{\prime \prime} \mathrm{S}$ and $30^{\circ} 06^{\prime} 30^{\prime \prime} \mathrm{W}$, at an altitude of $680 \mathrm{~m}$. Mean annual rainfall is $1750 \mathrm{~mm}$, with a dry and cold period (April to September) and a rainy and warm period (October to March). Mean maximal and minimal annual temperatures are approximately $27.8^{\circ} \mathrm{C}$ and $16.9^{\circ} \mathrm{C}$, respectively.

The animals were managed on a rotational pasture system on Brachiaria brizantha cv. Marandu and Panicum maximum cv. Tanzânia grasses and received citrus pulp supplementation and citrus feed, as well as mineral salt throughout the year. During the dry season, they received a grass silage supplement. The greatest number of parities occurred from February to April.

The data for MY at each monthly test day were obtained from two hand milkings (0500 and $1700 \mathrm{~h}$ ). The milk constituents were obtained from the morning milking and analyzed by infrared absorption (Bentley 2000 instrument; Chaska, MN). SCC was determined by flow cytometry (Somacount 300 cell counter; Bentley 2000).

For analysis of the SCC variable on the test day, the transformation $\mathrm{SCCt}=\left\{\left[\log _{2}(\mathrm{SCC} / 100,000)\right]+3\right\}$ was used (Dabdoub and Shook, 1984). The mixed-model methodology was used according to a repeated-measures scheme, as well as the restricted maximum likelihood method (REML) available in the MIXED software of SAS (1995). In general, the model can be represented as:

$$
y_{i j k l m}=\alpha+v_{i}+a_{j}+o_{k}+c_{l}+(o c)_{k l}+e_{i j k l m}
$$

where $y_{i j k l m}=$ test day of SCCt; $\alpha=$ intercept; $v_{i}=$ random effect of the $i$ th buffalo, with mean $=0$ and variance $=1 ; a_{j}=$ fixed effect of the $j$ th calving year $(j$ $=1997, \ldots, 2000) ; o_{k}=$ fixed effect of the $k$ th calving order $(k=1, \ldots, 5) ; c_{l}=$ fixed effect of the $l$ th month of lactation $(l=1, \ldots, 10) ;(o c)_{k l}=$ fixed effect of interaction the $k$ th calving order and the $l$ th month of lactation, and $e_{l j k l m}=$ residue.

The analysis of milk and milk constituents percentage on the test day was carried out according to the mixed-model method applied to a scheme with repeated measures and heterogeneous slopes for the linear effect of SCCt on the month of lactation. In general, the model can be presented as:

$$
\begin{gathered}
y_{i j k l m n}=\alpha+v_{i}+a_{j}+o_{k}+c_{l}+(o c)_{k l}+\beta_{l}\left(x_{m l}-\bar{x}_{l}\right) \\
+e_{i j k l m n}
\end{gathered}
$$

where $y_{i j k l m}=$ test-day $\mathrm{MY}$ and $\% \mathrm{~F}, \% \mathrm{P}, \% \mathrm{LT}$, and $\% \mathrm{TS}$; $\alpha=$ intercept; $v_{i}=$ random effect of the $i$ th buffalo, with mean $=0$ and variance $=1 ; a_{j}=$ fixed effect of the $j$ th calving year $(j=1997, \ldots, 2000) ; o_{k}=$ fixed effect of the $k$ th calving order $(k=1, \ldots, 5) ; c_{l}=$ fixed effect of the $l$ th month of lactation $(l=1, \ldots, 10) ;(o c)_{k l}=$ fixed effect of interaction the $k$ th calving order and the $l$ th month of lactation; $\beta_{l}=$ linear regression coefficient for SCCt in the $l$ th month of lactation; $x_{m l}=m$ th SCCt in the $l$ th month of lactation; $\bar{x}_{l}=$ mean SCCt in the $l$ th month of lactation, and $e_{l j k l m n}=$ residue.

Due to the seasonality of calving (February to April), the month or station of calving and calendar month of test were omitted from the models. 
Table 2. Arithmetical mean $( \pm \mathrm{SD})$, median, and mode for SCC in the different linear scores in buffalo milk. ${ }^{1}$

\begin{tabular}{|c|c|c|c|c|c|c|c|c|}
\hline \multirow{2}{*}{$\begin{array}{l}\text { Linear } \\
\text { score }\end{array}$} & \multirow[b]{2}{*}{ SCC } & \multirow{2}{*}{$\begin{array}{l}\text { Number of } \\
\text { observations }\end{array}$} & \multicolumn{2}{|c|}{ Mean } & \multicolumn{2}{|c|}{ Median } & \multicolumn{2}{|c|}{ Mode } \\
\hline & & & SCC & SCCt & SCC & SCCt & SCC & SCCt \\
\hline 0 & $0-17$ & 1014 & $10.1 \pm 4.2$ & $-0.48 \pm 0.81$ & 10 & -0.32 & 11 & -0.18 \\
\hline 1 & $18-34$ & 665 & $24.9 \pm 4.7$ & $0.97 \pm 0.27$ & 25 & 1.00 & 19 & 0.60 \\
\hline 2 & $35-70$ & 472 & $48.4 \pm 10.3$ & $1.92 \pm 0.30$ & 47 & 1.91 & 36 & 1.52 \\
\hline 3 & $71-140$ & 296 & $99.6 \pm 20.3$ & $2.96 \pm 0.29$ & 98 & 2.97 & 72 & 2.52 \\
\hline 4 & $141-282$ & 161 & $188.9 \pm 37.9$ & $3.89 \pm 0.28$ & 182 & 3.86 & 146 & 3.54 \\
\hline 5 & $283-565$ & 55 & $384.7 \pm 75.3$ & $4.91 \pm 0.27$ & 369 & 4.88 & 305 & 4.60 \\
\hline 6 & $566-1130$ & 17 & $750.3 \pm 204.7$ & $5.86 \pm 0.36$ & 634 & 5.66 & 581 & 5.53 \\
\hline 7 & $1131-2262$ & 8 & $1586.3 \pm 280.7$ & $6.96 \pm 0.26$ & 1520 & 6.92 & 1202 & 6.58 \\
\hline 8 & $2263-4525$ & 4 & $2533.5 \pm 462.6$ & $7.64 \pm 0.24$ & 2317 & 7.53 & 2274 & 7.50 \\
\hline 9 & $>4525$ & 1 & 5228 & 8.70 & 5228 & 8.71 & 5228 & 8.71 \\
\hline Total & & 2693 & $63.61 \pm 185.69$ & $1.13 \pm 1.68$ & 25 & 1 & 11 & -0.18 \\
\hline
\end{tabular}

${ }^{1}$ Classes of linear scores defined by Shook (1982); SCC = per 1000/ml; SCCt $=$ transformed SCC.

\section{RESULTS AND DISCUSSION}

The arithmetical mean $( \pm \mathrm{SD})$, median, and mode of SCC were $63,610 \pm 185,690 ; 25,000$, and 11,000 cells/ $\mathrm{ml}$, respectively (Table 2 ). The mean value was low compared to that obtained from buffaloes in Bulgaria (Petrova amd Tzamkova, 1999). According to Guidry (1985), values lower than 283,000 cells $/ \mathrm{ml}$ do not reflect the health of the udder, but rather are associated with MY (Hortet et al., 1999). In this study, only $3.2 \%$ of the test-day SCC exceeded 282,000 cells $/ \mathrm{ml}$.

All the effects considered in the model were highly significant $(P<0.001)$. Figure 1 shows the relationships of the month of lactation and SCCt by parity. In the first parity, the SCC was lower than in all other parities in all the months of lactation. In a study conducted by Shepers et al. (1997), the natural log of SCC from uninfected quarters of first-parity cows was highest during the first part of the lactation because of the relatively flat SCC curve, although the mean natural log of SCC in first-parity cows was lowest.

In all of the parities, SCCt decreased in the second month of lactation and then increased thereafter up to the ninth month. This result could be attributed to lesions caused by daily milking or even to the progress of bacterial infections over the lactation period or throughout the lactation due to a dilution effect (Reneau, 1986).

In cattle, the logarithm of SCC was high at the beginning of the lactation, dropped to a minimum between 40 and $80 \mathrm{~d}$ postpartum, and then steadily increased until the end of lactation (Schepers et al., 1997). In the work of Rodriguez-Zas et al. (2000), the SCCt decreased to a nadir at about $60 \mathrm{~d}$ of lactation and then increased-although not in a monotonic mode-without regaining the initial level. Rather, SCC increased in older cattle and/or at the end of lactation due to an increased prevalence of infection and permanent glandular damage from previous infections (Bartlett et al., 1990).

ANOVA applied to MY showed that the fixed effects of order and year of parturition were highly significant $(P<0.01)$. These results may reflect physiological changes in the animals and changes in management and genetic constitution of the herd with time. There was also a highly significant difference between orders of month of lactation. The interaction parity and month of lactation effect were significantly different $(P<0.01)$. Figure 1 shows that in all parities, MY was greater in the second month of lactation and then decreased. The adjusted mean in the first month of lactation was $6.87 \mathrm{~kg}$, with an increase to $7.55 \mathrm{~kg}$ in the second month, and a later decrease until the end of lactation.

Analysis of milk constituents showed highly significant differences for fixed effects of calving year, calving order, and month of lactation. The interaction order of parity by month of lactation effect showed a highly significant difference for lactose $(P<0.01)$. For protein, fat, and TS, the interaction parity by order of month was not significant $(P=0.051,0.063$, and 0.11 , respectively). In the different months of lactation, $\% \mathrm{~F}, \% \mathrm{P}$, \%LT, and \%TS ranged from 6.28 to $8.38 \%, 4.05$ to $4.59 \%, 4.96$ to $5.34 \%$, and 16.94 to $18.55 \%$, respectively (Figure 1). These values are close to those reported in the literature, which range from 6.71 to $7.65 \%$ for $\% \mathrm{~F}$ and from 3.60 to $4.36 \%$ for \%P (Macedo et al., 1997; Sindhu and Singhal, 1988; Tonhati et al., 2000). Sindhu and Singhal (1988) detected values of 4.83 to 5.48\% for lactose, and Macedo et al. (1997) and Sindhu and Singhal (1988) reported values of 15.75 to $18.99 \%$ for TS. The peaks of MY, \%F, \%P, \%LT and \% TS occurred in the second, ninth, first, and ninth months of lactation, respectively, in agreement with literature reports. 

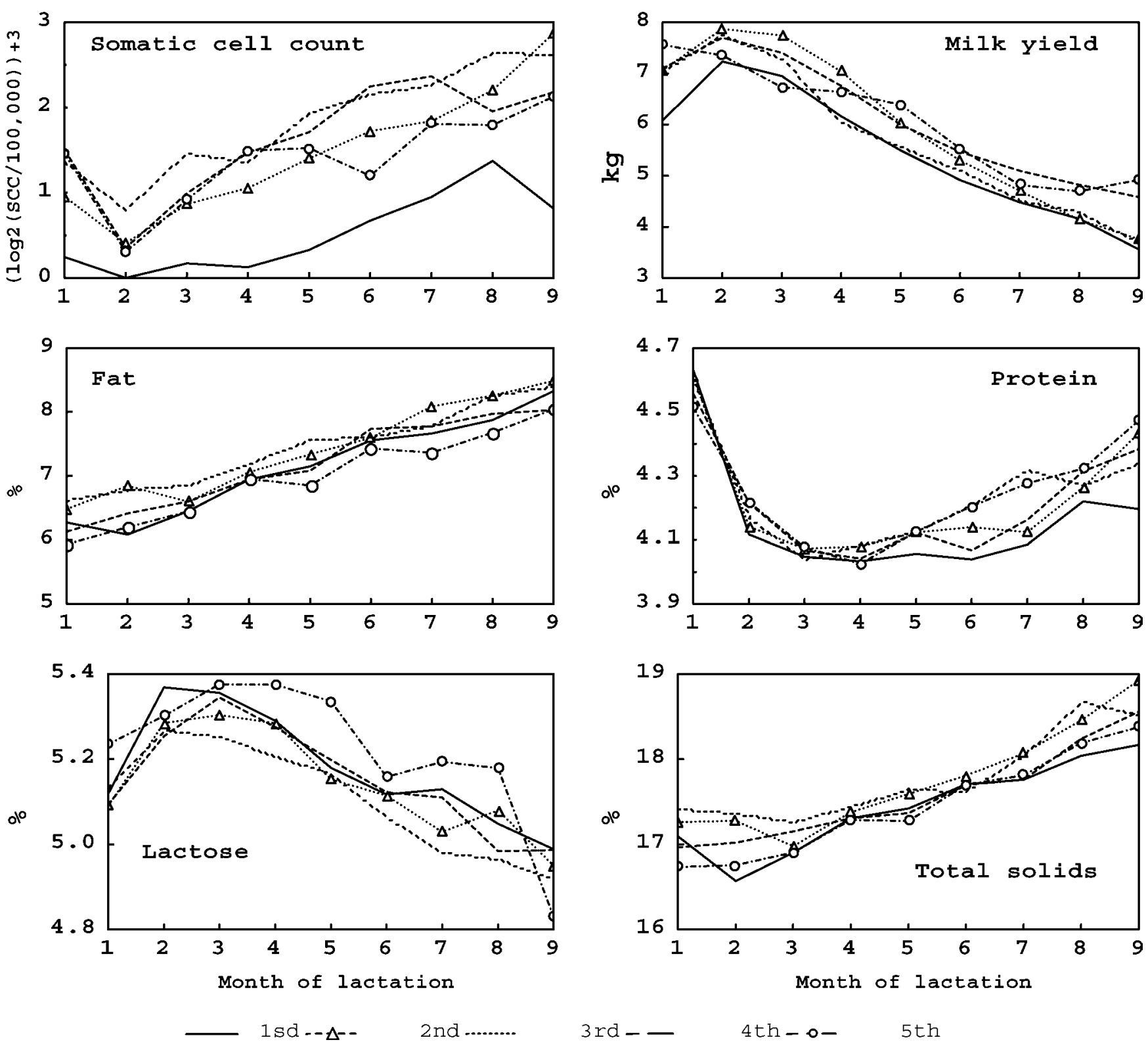

Figure 1. Adjusted means for transformed SCC, milk yield, and percentages of fat, protein, lactose, and TS for the different calving orders (first through fifth) and month of lactation in buffalo milk.

The regression for SCCt showed highly significant differences in all months of lactation for test-day MY and \%LT yields, with negative regression coefficients $\left(\beta_{l}\right)$ for SCCt indicating a reduction in milk and lactose yield. This result is expected for MY reduction as a consequence of the infection of the mammary gland by pathogenic bacteria that vary according to the intensity and duration of the infection (Eberhart et al., 1987). Elevated SCC are associated with a decrease in lactose because of reduced synthetic activity of the mammary tissue (Harmon, 1994).
The regressions of SCCt on $\% \mathrm{~F}$ were highly significant for all months except the eighth month; on $\% \mathrm{P}$, they were highly significant in the first and third months; on \% TS, they were highly significant in the fourth, sixth, and seventh months $(P<0.01)$. The $\% \mathrm{~F}$, $\% \mathrm{P}$, and \% TS increased with greater SCCt. Kitchen (1981) found no change in fat content, yet total fat yield decreased because of a decline in milk production. Weaver and Kroger (1977) and Ng-Kwai-Hang et al. (1982) observed a significant increase in total protein and noncasein protein as SCC increased. According to 
the review of Kitchen (1981) cited by Harmon (1994), some studies have shown no change in fat content, but found a decrease in total fat yield because of a decline in milk production.

\section{CONCLUSIONS}

The results obtained permitted us to infer that high SCC has a negative effect on milk and lactose yield in buffaloes, causing losses to producers due to reduced milk production and quality. Therefore, tests for the detection of mastitis should be set up for buffalo herds in order to improve the hygienic quality of milk, thus also improving the quality of products offered on the market.

\section{REFERENCES}

Bartlett, P. C., G. Y. Miller, C. R. Anderson, and J. H. Kirk. 1990. Milk production and somatic cell count in Michigan Dairy Herds. J. Dairy Sci. 73:2794-2800.

Beaudeau, F., A. Henken, C. Fourichon, K. Frankena, and H. Seegers. 1993. Associations between health disorders and culling of dairy cows: A review. Livest. Prod. Sci. 35:213-236.

Costa, E. O., E. T. Watanabe, A. R. Ribeiro, F. Garino Jr., A. M. Houriti, and P. S. Baruselli. 2000. Mastitis bubalina: etiologia, índices de mastitis clínica e subclínica. Napgama 1:12-15.

Dabdoub, S. M., and G. E. Shook. 1984. Phenotypic relations among milk yield, somatic cell count and clinical mastitis. J. Dairy Sci. 67(Suppl. 1):163-164.

Eberthart, R. J., R. J. Harmon, D. E. Jasper, R. P. Natzke, S. C. Nickerson, J. K. Reneau, E. H. Row, K. L. Smith, and S. B. Spencer. 1987. Current concepts of bovine mastitis. 3rd ed. Natl. Mastitis Counc., Inc., Arlington, VA.

Gill, R., W. Howard, K. Leslie, and K. Lissemore. 1990. Economics of mastitis control. J. Dairy Sci. 73:3340-3348.

Guidry, A. J. 1985. Mastitis and the immune system of the mammary gland. Pages 262-299 in Lactation. B. L. Larson, ed. The Iowa State University Press, Ames, IA.

Harmon, R. J. 1994. Symposium: Mastitis and genetic evaluation for somatic cell count-Physiology of mastitis and factors affecting somatic cell counts. J. Dairy Sci. 77:2103-2112.
Hortet, P., F. Beaudeau, H. Seegers, and C. Fourichon. 1999. Reduction in milk yield associated with somatic cell counts up to 600,000 cells/ml in French Holstein cows without clinical mastitis. Livest. Prod. Sci. 61:33-42.

Jones, G. M. 1986. Symposium: Reducing somatic cell counts: Meeting the 1986 challenge-Impact on producer and processor. J. Dairy Sci. 69:1699-1707.

Kitchen, B. J. 1981. Review of progress of dairy science: Bovine mastitis:milk compositional changes and related diagnostic test. J. Dairy Res. 48:167-188.

Lescourret, F., and J. Coulon. 1994. Modeling the impact of mastitis on milk production by dairy cows. J. Dairy Sci. 77:2289-2301.

Macedo, M., J. Sousa, F. Wechsler, A. Ramos, M. Kawatoko, G. Camargo, J. Mattos, and J. Amaral. 1997. Chemical composition of milk from Mediterranean buffalo cows raised in Brazil. Pages 213-216 in Proc. 5th World Buffalo Congr., Caserta, Italy. Cercola, Italy.

Ng-Kwai-Hang, K. F., J. F. Haynes, J. E. Moxley, and H. G. Monardes. 1982. Environmental influences on protein content and composition of bovine milk. J. Dairy Sci. 65:1993-1998.

Petrova, N., and M. Tzankova. 1999. SCC of milk from three breeders of buffaloes in Shoumen region. Bulg. J. Agric. Sci. 5:895-900.

Reneau, J. K. 1986. Effective use of dairy herd improvement somatic cell counts in mastitis control. J. Dairy Sci. 69:1708-1720.

Rodriguez-Zas, S. L., D. Gianola, and G. E. Shook. 2000. Evaluation of models for somatic cell score lactation patterns in Holsteins. Livest. Prod. Sci. 67:19-30.

SAS. 1995. User's Guide. SAS Institute, Inc. Cary, NC.

Schepers, A. J., T. J. Lam, Y. H. Schukken, J. B. M. Wilmink, and W. J. A. Hanekamp. 1997. Estimation of variance components for somatic cell counts to determine thresholds for uninfected quarters. J. Dairy Sci. 80:1833-1840.

Shook, G. E., and M. Schultz. 1994. Selection on somatic cell score to improve resistance to mastitis in the United States. J. Dairy Sci. 77:648-658.

Shook, G. E. 1989. Selection for disease resistence. J. Dairy Sci. 72:1349-1362.

Sindhu, J. S., and O. P. Singhal. 1988. Quantitative aspects of buffalo milk constituents for products technology. Pages 263-281 in Proc. 2nd World Buffalo Cong. New Delhi, India.

Tonhati, H., M. F. Cerón-Muñoz, J. Oliveira, J. M. C. Duarte, T. Furtado, and S. Tseimazides. 2000. Parâmetros genéticos para a produção de leite, gordura e proteína em bubalinos. Rev. Bras. Zool. 29(Suppl. 1):1320-1325.

Weaver, J. C., and M. Kroger. 1977. Protein, casein, and noncasein protein percentages in milk with high somatic cell counts. J. Dairy Sci. 60:878-881.

Welper, R. D., and A. Freeman. 1992. Genetic parameters for yield traits of Holsteins, including lactose and somatic cell score. J. Dairy Sci. 75:1342-1348. 